the statement of facts, he will do well to examine his authority for his statements that I have called the solitary Salpa a nurse; that I have described a Cunina in which the "hydroid produces medusæ by gemmation ;" and that I believe "that the solitary Salpa is hermaphrodite."

$$
\text { Baltimore, July I4 }
$$

W. K. BROOKS

\section{COLONIAL AND FOREIGN REPORTS}

$T \mathrm{HE}$ annual reports of colonial botanical gardens, 1 Government plantations, museums, \&c., form at the present day no inconsiderable item of the literature of scientific progress in different parts of the world which constantly crowd an editor's table. These records become, year after year, of increasing importance as well as of increasing bulk, and it is right that their contents should be better known, so that they may become useful, and this can only be done by a wide distribution of the reports themselves, and attention drawn to them by other publications.

Taking a few of these reports, which have recently come to hand, in the order of their issue, we first find one from Wellington, New Zealand, under the following title, "Eighteenth Annual Report on the Colonial Museum and Laboratory," together with the "Fourteenth Annual Report on the Colonial Botanic Garden, I882-83." This Report treats of various branches of science, and, as might be expected, geology has its full share. In the observatory the principal work is said to have been the observation of the transit of Venus, Dr. Hector's account of his observation, which, he says, was written out within an hour after the transit, being given as an appendix. Under the head of Botanic Garden, after describing some successful experiments in planting wattles (species of Acacia), Dr. Hector refers to experiments in the cultivation of Sorghum, which, however, are said not to have been continued in the garden, but in the northern part of the colony, the results were very favourable, proving that quite as large a percentage of crystallisable sugar can be obtained in New Zealand as in America. "Recent improvements," it is said, "have been made in the machinery, and by the use of a vacuum evaporating pan all the causes of the former miscarriage in the production of the sugar appear to have been removed, so that there is every prospect of the growth of the Sorghum becoming an important industry in the north of New Zealand." A most interesting and important feature of the year is said to be the sudden expansion of the cultivation of hops in the colony. In Nelson it is shown that the cultivation has been most successful, and in the neighbourhood of Wellington the hop also grows well. The plants are subject more or less to attacks from the red spider and what is known as the plant louse, but they have not yet committed any great damage.

Mr. Morris's "Annual Report of the Public Gardens and Plantations for the year ended September 30, I883," shows that the usual operations of the department have been fully maintained, while the "chief scientific work of the year has been connected with the collection and determination of numerous native plants of the island which have been added to the Department Herbarium, and the large addition of others to the growing collections." Referring to the attacks by insects on the sugar cane, $\mathrm{Mr}$. Morris points out that the spasmodic or intermittent character of the attack is in accordance with their general habit in all parts of the world; "but," he says, "it is well for us to note their appearance and disappearance with great care, in order that we may thereby be prepared for their attacks, and reduce the amount of damage they do to our crops to a minimum."

The indiscriminate destruction of small birds in the island has attracted some attention, and measures have been suggested whereby it may be checked or perhaps stopped.
The mungoose, which has been imported from India to destroy rats on sugar estates, is stated to be increasing very rapidly, not only on sugar estates, but on the highest mountains along the shore, and even amidst swamps and lagoons. The sugar planters have greatly benefited by its introduction, rat-eaten canes being now scarcely known. The negro settlers and persons not connected with sugar estates complain of its ravages amongst their poultry, fruit, and vegetables. Mr. Morris says, however, that poultry is still fairly plentiful in country districts, and from his experience of the mungoose in confinement, the cresture is not likely to eat either sugar cane, banana, or field vegetables, except under the influence of extreme hunger, which would not occur so long as there are rats, mice, lizards, and other small animals to feed on. "The mungoose is, however," Mr. Morris says, "disturbing greatly the distribution of animal life in the island; and the harmless yellow and other snakes, lizards, groundhatching birds, the interesting cony, and many members of our indigenous fauna, are likely to become extinct at no distant period."

Under the head of cultivation and distribution of economic plants $\mathrm{Mr}$. Morris reports progress in many new products. It is not encouraging, however, to find that the cultivation of ginger in Jamaica appears to be dying out, due "to the smaller yield of plants cultivated so persistently on the same land, to the uncertain nature of the crop, no less than the difficulty experienced in many districts in curing it properly." Jamaica ginger has hitherto held a prominent position in the market as to quality, and it is a pity that its reputation should become a thing of the past.

The next report before us is that of Dr. Schomburgk, and treats of the "Progress and condition of the Botanic Garden and Government plantations" at Adelaide, South Australia. A similar work seems to be going on here as at most other colonial gardens at the present time, namely, the distribution of native, and the acclimatisation of foreign plants, chiefly of economic value. The Gardens seem to be very popular, as well as the Museum of Economic Botany, which is a comparatively new institution to Adelaide. Two appendices are added to Dr. Schomburgk's report, one consisting of a "Catalogue of Plants added during 1883 to those under cultivation in the Botanic Garden," arranged according to their natural orders, and the other a "List of Palma, Bromeliaceæ, Filices, and Lycopodiacex, cultivated in the Botanic Garden." The report is illustrated by eight views in the Gardens.

A Report of the Committee of Management for 1883 of the Technological Industrial and Sanitary Museum of New South Wales shows that a great deal of progress has been made in extending the utility of the Museum during the year. The Museum, which seems to have been opened so recently as December last, bids fair to become of very great service to the colony. One paragraph in the Report says, "Special endeavours are being made to collect the raw products and samples illustrative of the industries and manufactures of the Australian colonies, and the Committee have already secured a considerable number of native vegetable and mineral products and a comprehensive series of specimens of wool."

The "Annual Report of the Royal Botanic Garden, Calcutta, for the year $1883-84$," and that of the Government Cinchona Plantations in Bengal for the same period, are, as usual, very creditable to Dr. King as superintendent. Dr. King's reports are always concise and interesting records of admirable work both at the Botanic Garden and at the cinchona plantations, and those before us show that in the former a good deal of consideration has been paid during the year to the extension of plants of real commercial value, such, for instance, as paper materials, including the sabai grass (Pollinia eriopoda, Hance), and the 
paper mulberry (Broussonetia papyrifera, Vent), also fibrous plants, including the Rhea, or China grass (Boekmeria nivea, W. and A.). Much progress has been made in arranging the specimens in the new building which has been providedf or the herbarium, and numerous contributions have been received both to the herbarium and to the gardens. In the Report on the cinchona plantations Dr. King gives details of the year's crop, of the expenditure for the year, and of the progress of the several forms or varieties. At the factory the total out-turns for the year was $8714 \mathrm{lbs}$. of febrifuge, 250 lbs. of which were of the new crystalline preparation, which closely resembles the ordinary febrifuge, but, on examination, the grains are seen to be small crystals ; it differs, however, in constitution from the old febrifuge, inasmuch as it contains none of the amorphous alkaloid which is the ingredient in that preparation which causes the nausea which sometimes follows its administration. The efficiency of the staff both in the Calcutta Gardens and at the cinchona plantations is indicated by the testimony which Dr. King, with his usual frankness and consideration, bears to the ability of his subordinates.

From the Botanic Garden, Hong Kong, Mr. Charles Ford, the Superintendent of the Botanical and Afforestation Department, reports, under date April 30, 1884, of the department under his charge. A good many plants both of commercial and horticultural interest have been grown with more or less success, including the carob tree (Ceratonia Siliqua) of Southern Europe, the Chinese tea oil tree (Camellia drupifera), the Chinese varnish tree (Aleurites vernicia), and many others. A very interesting account of a visit to the Lo-fau-shan Mountains and a list of the plants collected is given in this Report.

\section{NOTES}

Her Majesty's Government, on the recommendation of the Lords of the Committee of Council on Education, have given their adhesion to the International Geodetic Association, and have nominated the undermentioned gentlemen as delegates of the United Kingdom to the Association, viz. :--The Director-General of the Ordnance.Survey (for the time being), Col. A. R. Clarke, R.E., F.R.S., the Astronomer-Royal, the Hydrographer of the Navy (for the time being), General J. T. Walker, R.E., C.B., F.R.S.

Two academic honours have recently, Science states, been conferred in the United States upon scientific men, which are worthy of note because more rare and costly than such distinctions usually are. At New Haven, on the day before commencement, a bronze statue of Prof. Silliman, for more than fifty years a teacher of chemistry, mineralogy, and geology in Yale College, and the founder of the American fournal of Science and Arts, was placed on its pedestal near the new chapel. The other honour is that of a medal struck at the U.S. Mint in Philadelphia, at the request of the colleagues and friends of Prof. Sylvester, to commemorate his residence in Baltimore during a period of seven years, marked, among other things, by the establishment of the American Fournal of Mathematics. The medal, in size and general aspect, is not unlike that which was struck in commemoration of the life of Agassiz. On one side is an accurate and spirited portrait of the mathematician, with the name Sylvester; on the reverse a Latin inscription commemorates the fact that he was for seven years Professor of Mathematics in the Johns Hopkins Universityfrom $r 876$ to $r 883$. The original medal in gold was sent to Prof. Sylvester, in his new home in the University of Oxford ; a duplicate in silver was retained in Baltimore, and a few impressions in bronze have been distributed among his scientific friends and correspondents.
Science, in referring to the recent researches of Koch, states that work of value upon the subject of micro-organisms is not done in this country (the United States), nor will it be until some such encouragement is offered to investigators as is the case in France and Germany. This kind of research requires the rare combination of many forms of training, added to a critical, analytical, and judicial mind. These we can have; but until the facilities for the work are offered, until the necessity for personal sacrifice and self-denial is done away with, we can hope for no better work in the future than has been done in the past; in other words, what is first needed in order to place our own investigations upon an equality with those of the two countries mentioned above, is a thoroughly-equipped, fullyendowed laboratory, with a strong corps of well-trained and salaried officials. These remarks might very well have been written concerning our own country, and the official mission of Dr. Klein to India is a tardy recognition by our Government of the necessity of State intervention if scientific research is to be pursued with any hope of speedy and substantial practical results. The true way to encourage such inquiries (Science truly says) lies in the establishment of a Commission composed of men thoroughly trained and qualified for the work, and then to treat it as the German Government has treated its Cholera Commission, that is, to give it full powers and funds to allow the prosecution of its labours to the end.

THE death is announced at the age of seventy-five years of Sir Erasmus Wilson, the eminent surgeon.

THE death is also announced of Mr. John Aitken, J.P., of Urmston, well known as a geologist in the northern counties. Deceased was born in 1820 . He was early distinguished for his application to scientific matters, and he twice filled the office of President of the Manchester Geological Society. He wrote for the Society's papers a number of articles relating chiefly to the geology of Clitheroe, Bacup, and Holcombe, and he also contributed to the Geological Magazine and the American Journal of Science. He furnished for Newbiggin's " History of the Forest of Rossendale" the geological section relating to that district.

Sir Jorn LuBbock has been compelled, for personal reasons, to abandon his intention of attending the meeting of the British Association at Montreal.

A COMmitTeE was appointed in 1882 at the Montreal meeting of the American Association for the Advancement of Science, "to confer with committees of foreign associations for the advancement of science with reference to an international convention of scientific associations." The committee consists of Dr. T. Sterry Hunt, Mr. Alexander Agassiz, and Prof. Simon Newcomb. If the British Association responds, as has been suggested, by also appointing a committee, the official channels for the interchange of opinion between the two national bodies will be suitably established on both sides. We (Scionce) are unable to make any authorised statement as to what the American committee has done or proposes, but its membership justifies the conviction that it is capable of efficient action, wisely planned. We shall await their report with interest.

The Committee appointed by the Government at M. Pasteur's request to verify his experiments in the treatment of hydrophobia has just presented its first report. M. Bouley is president, his colleagues being MM. Beclard, Paul Bert, Tisserand, Villemin, and Vulpian. The Committee states that M. Pasteur's experiments have been entirely borne out. Inoculation with the attenuated virus of hydrophobia gives a dog immunity from the disease, just as similar treatment preserves a sheep from charbon. All the twenty-three dogs submitted by M. Pasteur as having been thus inoculated have resisted the strongest virus on inoculation, whereas the majority of the nineteen non-inoculated dogs have suc- 